\title{
Yozgat İli Su Ürünleri Tüketim Alışkanlıklarının Belirlenmesi
}

\section{Naciye ERDOĞAN SAĞLAM*, Serap SAMSUN}

Ordu Üniversitesi, Fatsa Deniz Bilimleri Fakültesi, Ordu.

Geliş : 03.04.2017

Kabul : 11.10.2017

*Sorumlu yazar: nes-34@ hotmail.com

Araştırma Makalesi / Research Paper

E-Dergi ISSN: 1308-7517

Özet

$\mathrm{Bu}$ araştırma Yozgat ilinde yaşayan insanların balık tüketim alışkanlıklarının ve tercihlerinin ortaya konması amacı ile yapılmıştır. Veriler 2016 yılı içerisinde tesadüfi örnekleme yöntemine göre 17-67 yaş aralığında 270 kişi ile görüşülerek anket yolu ile elde edilmiştir. Yozgat'ta yaşayanların \%82'sinin balık tükettiği görülmüştür. Balık tüketim tercihini $\% 60,6$ ile en yüksek oranda sağlıklı ve dengeli beslenme oluştururken, tüketmeme nedenini ise \% 57,1 ile en fazla oranda balığı sevmeme oluşturmaktadır. Katılımcıların \%97,7'sinin taze, \%1,3'ünün dondurulmuş, $\% 1$ 'inin konserve ürünleri tercih ettikleri tespit edilmiştir. En çok tüketilen su ürünü \%94 ile hamsidir.

Anahtar kelimeler: Yozgat, balık tüketimi, tüketim tercihleri, su ürünleri

Determination of the Seafood Consumption Habits of Yozgat Province.

\begin{abstract}
This research has been conducted to display the fish consumption habits and preferences of people living in the Yozgat province. In 2016, the data were collected through questionnaires with 270 people in the age range 17-67 according to the random sampling method. $82 \%$ of participants consume fish. Fish consumption preference is highest with $60.6 \%$ while healthy and balanced nutrition constitute the most and the reason for not consuming is $57.1 \%$. It has been determined that $97.7 \%$ of the participants consume fish as a fresh, $1.3 \%$ frozen and prefer $1 \%$ preserves. Anchovy is the most consumed sea food with $94 \%$ consumption.
\end{abstract}

Keywords: Yozgat, fish consumption, consumption preferences, seafood

\section{GİRIŞ}

Su ürünleri protein, vitamin ve mineral açısından son derece zengin besinler olması nedeniyle insan beslenmesinde oldukça önemli bir yere sahiptir. Balık etinin diğer etlere nazaran daha yüksek protein ve mineral içerirken, daha az oranda yağ içermesi nedeniyle özellikle son yıllarda önemi ve tüketimi artmaktadır (Sayılı vd., 1999).

Dünya Sağlık Örgütü (WHO) verilerine göre sağlıklı bir insanın, vücut ağırlığının her kilogramı için, günde 1 gr protein tüketmesi ve bunun da \% 42'sinin hayvansal kökenli olması gerekmektedir (Anonim, 2013). Hızla artan ülke nüfusları, insan beslenmesinde önemli yeri olan hayvansal kökenli protein kaynaklarının yetersiz kalmasına neden olmaktadır. Bu protein açı̆̆ını en iyi derecede ve ucuz bir şekilde gidermede yararlanılacak kaynakların başında su ürünleri gelmektedir (Angiş, 2004).

Dünyada birçok ülkeye oranla ülkemizdeki su ürünleri tüketimi oldukça düşüktür. Kişi başına yıllık balık tüketim ortalaması İtalya'da $24,6 \mathrm{~kg}$. Fransa' da $31,2 \mathrm{~kg}$, İspanya' da 44,7 $\mathrm{kg}$, Japonya'da 70,6 kg, İzlanda' da $91,0 \mathrm{~kg}$ ve dünya ortalaması ise $15-16 \mathrm{~kg}$ iken ülkemizde 2015 y1lında 6,2 kg olarak belirlenmiştir (FAO, 2004; TÜİK, 2015). 
Dünyada su ürünleri tüketimi üzerine yapılmış birçok çalışma bulunmasına rağmen (Purcell ve Raunikar, 1968; Nash ve Bell, 1969; Pippin ve Morrison, 1975; Rodolfo vd., 1995; Verbeke vd., 2007; Pieniak vd., 2008; Pieniak vd., 2010), ülkemizde ise bu konudaki çalışmalar son yıllarda yoğunlaşmıştır (Şenol ve Sayg1, 2001; Çolakoğlu vd., 2006; Sayg1 vd., 2006; Cevger vd., 2008; Adıgüzel vd., 2009; Erdal ve Esengün, 2008; Yüksel vd., 2011; Aydın ve Karadurmuş, 2012).

$\mathrm{Bu}$ çalışma kıyı bölgelerine uzak Yozgat ilinde yaşayan halkın su ürünleri tüketim davranışlarının belirlenmesi ve tüketime etki eden nedenlerin ortaya konulması açısından önemlidir.

\section{MATERYAL ve YÖNTEM}

$\mathrm{Bu}$ araştırma Yozgat İli’nde yaşayan insanların su ürünleri tüketiminin belirlenmesi amacıyla 2016 yılı içerisinde tesadüfi olarak seçilen 270 katılımcı ile yüz yüze görüşülerek 24 sorudan oluşan anket çalışması ile yürütülmüştür. Katılımcıların bölge halkından olmasına özen gösterilmiştir. Uygulanan ankette katılımcıların sosyo-ekonomik durumları, su ürünleri tüketim davranışları, tüketilen balık türleri, ne sıklıkta tüketildiği, tüketim şekli, besin olarak su ürünlerini tercih nedenleri vb. sorular sorulmuştur. İstatistiksel değerlendirmede ki-kare analizinden yararlanılmıştır.

\section{BULGULAR}

Ankete katılanların 159'u (\%59) erkek ve 111'i (\%41) kadındır. Katılımcıların yaşları 1667 yaş aralığında olup, \%30,9'unun ilköğretim mezunu, \%39,6'sının lise mezunu, \%25,5'inin üniversite mezunu, \%4'ünün ise okuryazar olmadığı görülmüştür. Eğitim durumlarına göre “balık tüketiyor musunuz?” sorusuna ilköğretim mezunlarının \% 81,93'ü, lise mezunlarının \% 81,31 'i, üniversite mezunlarının \% 92,65'i ve okur-yazar olmayanların \% 25'i evet cevabını vermiştir (Şekil 1). Öğrenim durumlarına göre balık tüketenlerin oranı birbirine yakın iken okur-yazar olmayanlarda balık tüketim oranı düşüktür. Farklı eğitim düzeylerindeki kişilerin balık tüketim durumları arasındaki farkın önemli olmadığı belirlenmiştir ( $p>0,05)$. İlköğretimlise-üniversite mezunlarının balık tüketim durumu ile okur-yazar olmayanların balık tüketim durumları arasındaki fark istatistiksel olarak önemlidir $(\mathrm{p}<0,05)$.

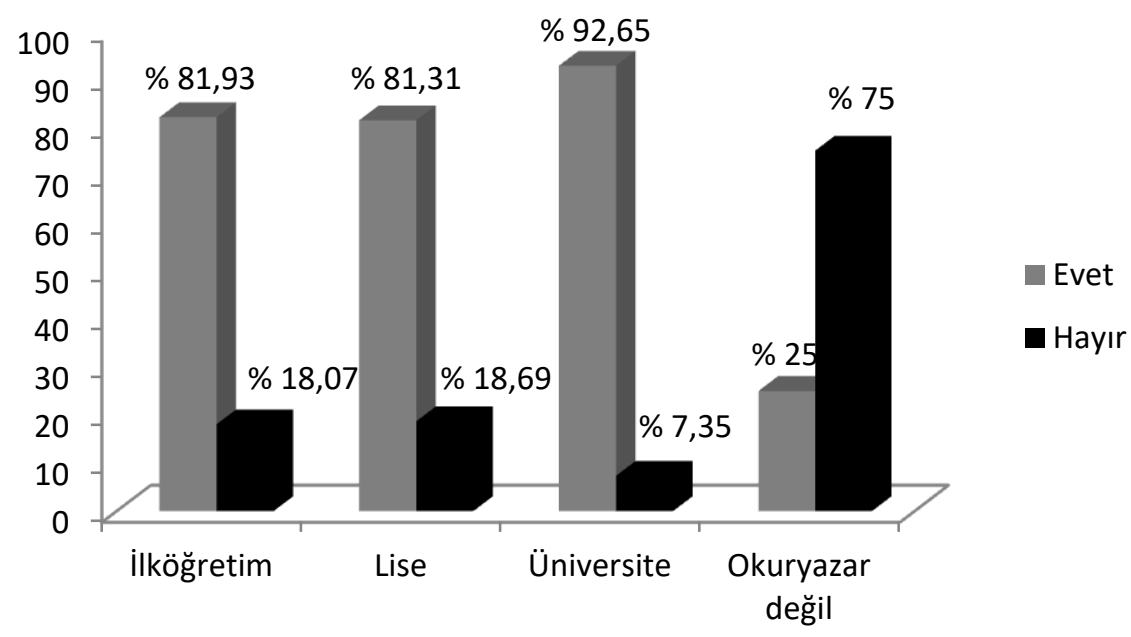

Şekil 1. Katılımcıların eğitim durumlarına göre balık tüketim tercihleri 
Farklı meslek gruplarında yer alan kat1lımc1ların \%21,4'ünün memur, \%20,8'inin ev hanımı, \%19,4'ünün işçi, \%18,5'inin serbest meslek, \%12,2'sinin çiftçi, \%5'inin emekli ve $\% 2,7$ 'sinin öğrenci olduğu gözlemlenmiştir (Şekil 2).

Ankete katılanların aylık aile gelirleri mesleklere göre farklılık göstermiş olup, kamu görevlilerinin aile gelirleri diğer meslek gruplarının aile gelirlerinden istatistiksel olarak yüksek bulunmuştur $(\mathrm{p}<0,05)$.

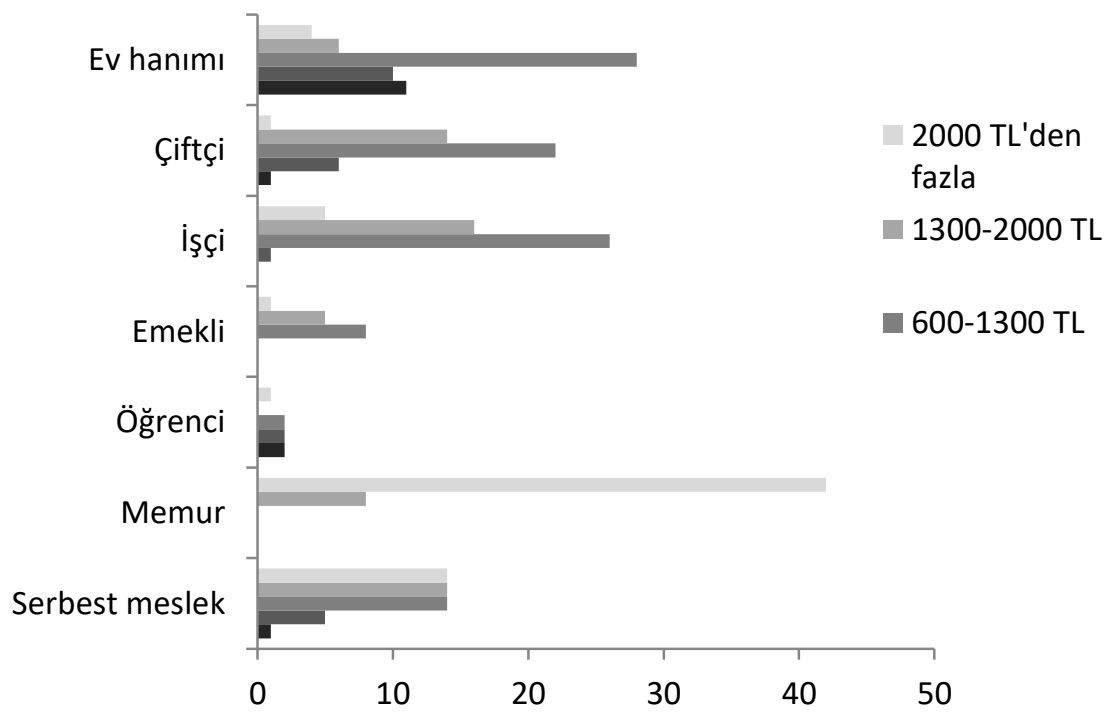

Şekil 2. Katılımcıların meslek dağılımlarına göre aylık gelir düzeyleri

Anket katılımcılarının balık tüketim alışkanlığının şehir merkezinde yaşayanlarda köy ve kasabada ikamet edenlere oranla daha yüksek olduğu tespit edilmiştir (Şekil 3). Köy ve kasabada yaşayanların protein ihtiyaçlarını diğer besin kaynaklarından karşıladıkları anlaşılmaktadır.

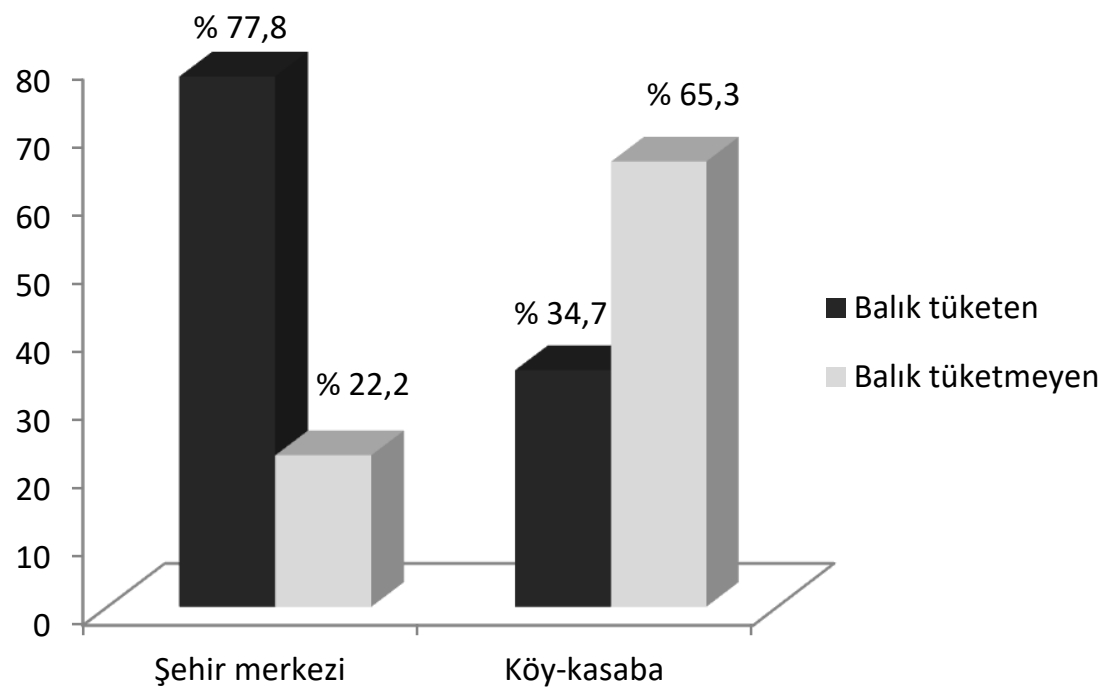

Şekil 3. Katılımcıların yerleşim yerlerine göre balık tüketim miktarları 
Katılımcıların \%82'si balık tüketirken, \%18'i tüketmediğini belirtmiştir. Balık tüketen katılımcıların balık tercihlerindeki sebep sorulduğunda, \%60,6'sı yalnızca sağlıklı ve dengeli beslenmek için, \%34,8'i lezzetli olması, \%3,2'si ekonomik bulması, \%1'i aile alışkanlığı ve $\% 0,6$ 's1 doktor tavsiyesi üzerine balık tükettiklerini ifade etmişlerdir. Balık tüketmeyen katılımcıların \%57,1'i balığı sevmeme, \%38,8'i pahalı ve ulaşmada zorluk olması, \%4,1'i ise tat ve kokusundan hoşlanmaması sebebi ile balık tüketmediğini belirtmiştir. Balık tüketenlerin \%59,2'si balık fiyatlarını pahalı, \%39,8'i normal ve \%1,0'1 ucuz bulduğunu bildirmiştir. Balık tüketmeme sebebi olarak damak tadına uymaması, aile alışkanlığı ve pahalı bulunması gerekçe gösterilmiştir.

Katılımcıların aylık balık tüketim miktarı incelendiğinde 13 kişi $10 \mathrm{~kg}$ ve üzeri balık tüketirken 132 kişi 1-3 kg arasında balık tüketmektedir (Şekil 4).

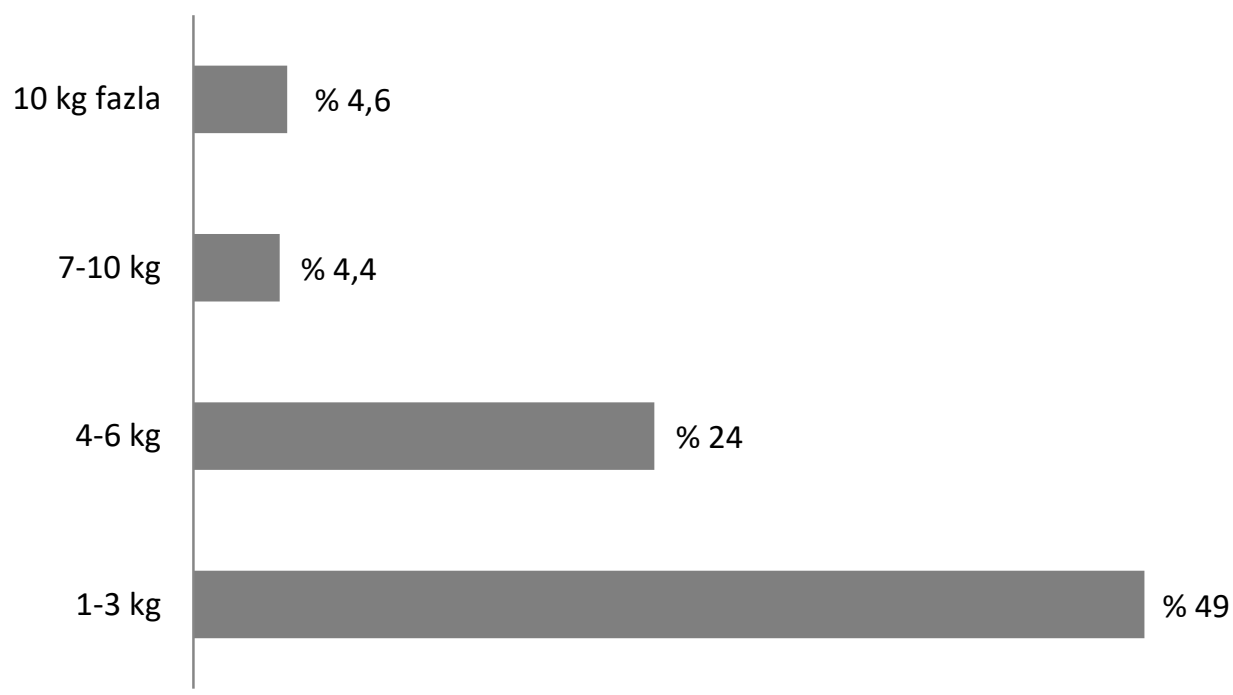

Şekil 4. Aylık su ürünleri tüketim oranları

Balık tüketme sıklığını belirlemek amacıyla sorulan sorulara göre \%51,6'sının ayda bir, $\% 31,2$ 'sinin haftada bir, \%11,3'ünün 3 ayda bir, \%5,4'ünün 6 ayda bir ve \%0,5'inin yılda bir tükettiği belirlenmiştir. Balık tüketme biçimi incelendiğinde katılımcıların \%97,7'si taze, $\% 1,3$ 'ü dondurulmuş ve $\% 1$ 'i ise konserve olarak tükettiğini ifade etmiştir.

"En çok tükettiğiniz balık hangisidir?" sorusuna katılımcıların \%94'ü hamsi cevab1 vermiştir. Balık tüketiminde sazan, alabalık, palamut, çipura, levrek ve somon gibi balık türleri geriye kalan \%6'l1k kısmı oluşturmaktadır. Yapılan araştırmaya göre ülkemizde en çok avcılığı ve tüketimi yapılan hamsinin, Yozgat ilindeki tüketicilerin de öncelikli tercihini oluşturduğu görülmüştür. Tüketicilerin balığı temin yeri olarak \%63,8'i pazaryeri, \%35,2'si balıkçı ve \%1'i süpermarketten satın aldığını belirtmiştir. Balık tüketenlerin pişirme yöntemi olarak \%51,6'sının firında pişirme, \%47,1'inin kızartma ve \%1,3'ünün rzgarada pişirmeyi tercih ettiği tespit edilmiştir.

Tüketicilerin \%53,4'ü balık satın aldığı yeri sağlıksı bulur iken \%46,6'sı sağlıklı ve hijyenik bulduğunu bildirmişlerdir.

Balık tüketenlerin "Alabalık gibi su ürünlerinin konservesi yapılsa tüketir misiniz?" sorusuna, 138'i hayır yanıtı verirken 83'ü evet yanıtı vermiştir (Şekil 5). 


\section{Alabalık gibi su ürünlerinin konservesi yapılsa tüketir misiniz?}

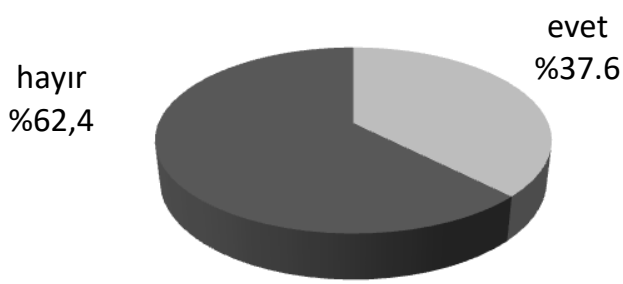

Şekil 5. Alabalık gibi su ürünlerinin tüketim şekli tercihi

Balık tüketiminin arttırılması için ne yapılması gerektiği sorusuna, katılımcıların \%47,7'si indirim yapılmalı, \%28,3'ü balık tüketimi hakkında bilgi arttırılmalı, \%14,2'si yetiştiricilik artmalı ve $\% 9,8$ 'i ise iç kesimlerde balık tüketiminin arttırılması için daha fazla balık gönderimi sağlanmalı şeklinde cevap vermişlerdir.

İnsan sağlığı açısından balık tüketiminin önemi hakkında tüketicilerin \%43'ünün orta, \%28,9'unun az, \%20'sinin çok ve \%8,1'inin hiç bilgi sahibi olmadığı tespit edilmiştir. Şekil 6'da katılımcıların balığın faydalarını nereden öğrendikleri belirtilmiştir.

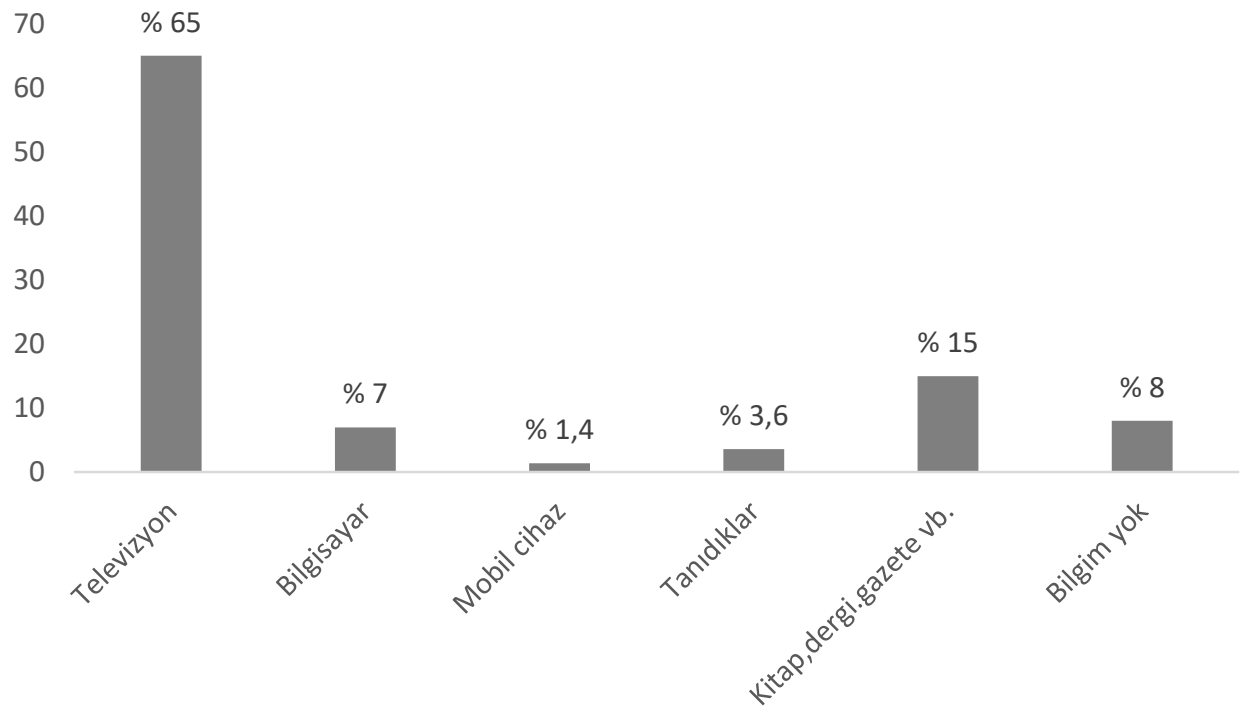

Şekil 6. Katılımcıların balığın faydalarını öğrenme şekilleri.

\section{TARTIŞMA ve SONUÇ}

$\mathrm{Bu}$ çalışma Yozgat İlindeki su ürünleri tüketim alışkanlıklarının belirlenmesi amacıyla yürütülmüştür. Yaşları 16 ile 67 arasında değişen \%59'u erkek, \%41'i bayan 270 katılımcının \%39,6'sı lise, \%30,9'u ilköğretim, \%25,5'i üniversite mezunu olup \%4'ü okuryazar değildir. Eğitim durumlarına göre balık tüketim oranına bakıldığında ilköğretim, lise ve üniversite 
mezunlarının balık tüketim oranları \%60'1n üzerinde olup okuryazar olmayanların balık tüketim oranı \%10'un altındadır. Çolakoğlu vd. (2006) eğitim düzeyi farkının balık tüketim tercih sebebinde etkili olmadığını ve yaklaşık \%40’lık kesimin lezzeti nedeniyle de balık tükettiklerini belirtmişlerdir.

Anket sonucuna göre katılımcıların \%70’i şehir merkezinde, \%30’u ise köy-kasabada yaşamaktadır. Şehir merkezinde yaşayanların balık tüketim oranının köy ve kasabada yaşayanlara göre daha fazla olduğu tespit edilmiştir. Bunun nedeni olarak daha iç kesimlere balık ulaşımının maliyet yönünden fazla olması nedeniyle şehir merkezlerinde balık satışına ağırlık verildiği söylenebilir. Balık tüketim tercihlerine yönelik nedenler sorulduğunda \%60,6'sı dengeli ve sağlıklı beslenmek cevabını vermiştir. Aydın ve Karadurmuş (2013) çalışmalarında su ürünleri tüketiminin $\% 45,95$ oranında sağlık yönünden tercih edildiğini belirtmişlerdir. Adıgüzel vd. (2009) araştırmalarında balık tüketen ailelerin \%53,19'unun balığı lezzetli olması nedeniyle tercih ettiklerini bildirirken bunu sırasıyla protein kaynağ1 olması, damak zevki, diğer etlere kıyasla ucuz olması, kolesterol açısından düşük olması, alışkanlık ve hazmı kolay olması izlemektedir. Yüksel vd. (2011) araştırmalarında balık tüketiminin \%31 oranında sadece sağlıklı ve dengeli beslenme, \%7 oranında sadece lezzet, $\% 62$ oranında ise her iki sebepten dolayı tercih edildiğini ifade etmişlerdir.

Katılımcıların \%8,1'inin balık tüketiminin insan sağlığı açısından önemi hakkında bilgi sahibi olmadığı, \%28,9'unun ise az bilgi sahibi olduğu tespit edilmiştir. Tüketim alışkanlığı, lezzeti, fiyatı gibi nedenlerden dolayı balık tüketim tercihi değişmekle birlikte balık tüketiminin insan sağlığı açısından önemi konusunda belirli bir seviyede bilgi sahibi oldukları anlaşılmaktadır. Balık tüketmeyen katılımcıların \%38,8'inin pahalı olmasını gerekçe göstermesi ve memurlar dışında diğer meslek gruplarında gelir düzeyinin 600-1300 TL arasında olması, balık tüketiminde gelir düzeyinin etkili olduğunu göstermektedir. Aydın ve Karadurmuş (2013) su ürünleri tüketilmeme sebeplerini pişirme ve yeme zorluğu, pahalı olması ve aile kültüründe yer almaması olarak belirtmişlerdir. Toplam aile geliri içerisinde gıda harcamasının payı ile aile geliri arasında ters yönde bir ilişki olup, aile geliri artıkça, bu gelirden gida harcaması için ayırılan değer mutlak değer olarak artarken, oransal olarak azalmaktadır (Adıgüzel vd., 2009). Gelir düzeyi balık tüketimini önemli ölçüde etkilemektedir. Gelir seviyesi yükseldikçe balık tüketim oranı da artmaktadır (Yüksel vd., 2011; Çolakoğlu vd., 2006).

Katılımcıların \%51,6'sı ayda bir, \%31,2'si ise haftada bir balık tükettiğini belirtmiştir. Aylık tüketim oranına bakıldığında \%49'u 1-3 kg arasında balık tüketirken, \%4,6’s1 $10 \mathrm{~kg}$ ve üzeri balık tüketmektedir. Hiç balık tüketmeyenlerin oranı ise \%18'dir. Balık tüketme biçimi ile ilgili olarak \%97,7'si taze tüketimi tercih ettiğini ifade etmiştir. Alabalık gibi su ürünlerini konserve olarak tüketir misiniz? sorusuna \%51'i hayır, \%31'i evet cevabını vermiştir. Aydın ve Karadurmuş (2013) Trabzon ve Giresun bölgelerinde yaptıkları çalışmalarında taze tüketim oranının \%95,14 olduğunu ifade etmişlerdir. Kişi başı yıllık balık tüketim miktarı Tokat İli Almus ilçesinde 14,71 kg (Adıgüzel vd., 2009), Trabzon ve Giresun İllerinde 29,52 kg (Aydın ve Karadurmuş, 2013), Tunceli İlinde 4,1 kg (Yüksel vd., 2011) olarak saptanmıştır. Yapılan çalışmalardan su ürünleri tüketim oranı düşük olmakla birlikte, tüketim şeklinin hem sahil hem de iç kesimlerde yüksek oranda taze olarak tercih edildiği görülmektedir. Yörede en çok tercih edilen balığın başında hamsi gelirken, \%63,8'i pazar yerinden, \%35,2'si balıçıdan, \%1'i ise marketten aldığını belirtmiştir. Katılımcıların \%53,4’ü satın aldığı yerin sağlıksız olduğunu belirtmiş olup balık satışının çoğunlukla pazar yerinde seyyar satıcılar tarafindan yapıldığı tespit edilmiştir.

Yozgat ilinde yapılan bu çalışmada halkın balık tüketiminin insan sağlı̆̆ açısından önemi konusunda yeteri kadar bilgi sahibi olmasına rağmen iç kesimlerde sahil kesimlerine göre 
balık fiyatlarının daha yüksek olması nedeniyle tüketim miktarının düştüğü görülmüştür. Aynı zamanda iç bölgelerde halkın balığa aşina olmaması ve damak zevki olarak tercih edilmemesi balık tüketim oranını azaltmaktadır.

Kıyısal bölgelere oranla tüketiminin daha az olduğu iç kesimlere su ürünlerinin daha ucuz maliyetle ulaştırılması amacıyla üretim-pazarlama-tüketim zincirinin geliştirilmesine yönelik çalışmalar üzerinde durulmalıdır. Bunun yanı sıra iç kesimlere gönderilen balık çeşitliliğinin arttırılması, iç su balıkları tüketiminin teşvik edilmesi, dengeli ve sağlıklı beslenme açısından su ürünlerinin önemine yönelik tanıtım çalışmalarına ağırlık verilmesi ile yöre halkının su ürünleri tüketimi arttırılabilir.

\section{KAYNAKLAR}

Adıgüzel, F., Civelek, O., Sayılı, M. \& Büyükbay, E. O. (2009). Tokat ili Almus ilçesinde ailelerin balık tüketim durumu. GOÜ Ziraat Fakültesi Dergisi 26(2), 35-43.

Angiş, S. (2004). Gökkuşağı Alabalığında soğuk tütsülemenin bazı önemli kimyasal ve duyusal özellikler üzerine etkisi. Atatürk Üniversitesi, Fen Bilimleri Enstitüsü, Yüksek Lisans Tezi, 36s, Erzurum.

Anonim, (2013). Hayvancılık Sektörü Raporu 2013. http://www.tigem.com.tr (Erişim tarihi: 05/06/2017)

Aydın, M. \& Karadurmuş, U. (2012). Consumer behaviors for seafood in Ordu province. SUMAE Yunus Araştırma Bülteni, 3, 18-23.

Aydın, M. \& Karadurmuş, U. (2013). Trabzon ve Giresun bölgelerindeki su ürünleri tüketim alışkanlıkları. Karadeniz Fen Bilimleri Dergisi. 3(9):57-71.

Cevger, Y., Aral, Y., Demir, P. \& Sarı̈zkan, S. (2008). Ankara Üniversitesi Veteriner Fakültesi intern öğrencilerinde hayvansal ürünlerin tüketim durumu ve tüketici tercihleri. Ankara Üniversitesi Veteriner Fakültesi Dergisi, 55, 189-194

Çolakoğlu, F.A., İşmen, A., Özen, Ö., Çakır, F., Yı̆̆ın, Ç. \& Ormancı, H.B. (2006). Çanakkale İli’ndeki su ürünleri tüketim davranışlarının değerlendirilmesi. Ege Üniversitesi Su Ürünleri Dergisi, 23(3), 387-392.

Erdal, G. \& Esengün, K. (2008). Tokat İli'nde balık tüketimini etkileyen faktörlerin logit model ile analizi. Ege Üniversitesi Su Ürünleri Dergisi, 25(3), 203-209

FAO, (2004). Fishery department. Databases and Statistics. (http://www.fao.org/fi/statist/ statist.asp)

Nash, D.A. \& Bell, F.W. (1969). An inventory of demand equations for fishery products, Bureau of Commercial Fisheries, U.S. Department of Commerce, working paper no: 10.

Pippin, K. \& Morrison, W.R. (1975). Retail market potential for farm-cultured catfish, Arkansas agricultural experiment station bulletin 799, Department of Agricultural Economics and Rural Sociology, University of Arkansas, Fayetteville.

Pieniak, Z., Verbeke, W., Perez-Cueto, F., Brunso, K. \& DeHenauw, S. (2008). Fish consumption and its motives in households with versus without self-reported medical history of CVD: A consumer survey from five European countries. BMC Public Health, 8(1), 306.

Pieniak, Z., Verbeke, W. \& Scholderer, J. (2010). Health-related beliefs and consumer knowledge as determinants of fish consumption. Journal of Human Nutrition and Dietetics, 23(5), 480-488.

Purcell, J.C. \& Raunikar, R. (1968). Analysis of demand, fish and shellfish. Bureau of Commercial Fisheries, U.S. Department of Commerce, Research Bulletin No. 51, Washington, D.C.

Rodolfo, M., Nayga, J. \& Capps, O. (1995). Factors affecting the probability of consuming fish and shellfish in the away from home and at home markets. Journal Agriculture and Applied Ecology, 27, 161-171.

Saygı, H., Saka, Ş., Fırat, K. \& Katağan, T. (2006). İzmir merkez ilçelerinde kamuoyunun balık tüketimi ve balık yetiştiriciliğine yaklaşımı. Ege Üniversitesi Su Ürünleri Dergisi, 23(1-2), 133 138. 
Sayıl1, M., Esengün, K., Kayım, M. \& Akça. H. (1999). The Econometric analysis of the factors affecting fish consumption in Tokat center county. Gaziosmanpaşa Üniversitesi Ziraat Fakültesi Dergisi, 16, 9-27.

Şenol, Ş. \& Sayg1, H. (2001). Su ürünleri tüketimi için bir ekonometrik model, E.Ü. Su Ürünleri Dergisi 18(3-4), 383-390

TÜİK, (2015). Su Ürünleri İstatistikleri. Türkiye İstatistik Kurumu, Ankara.

Verbeke, W., Vanhonacker, F., Sioen, I., Van Camp, J. \& DeHenauw, S. (2007). Perceived importance of sustainability and ethics related to fish: A consumer behavior perspective. AMBIO: A Journal of the Human Environment, 36(7), 580-585.

Yüksel, F., Karaton-Kuzgun, N. \& Özer, E.İ. (2011). Tunceli ili balık tüketim alışkanlığının belirlenmesi. Karadeniz Fen Bilimleri Dergisi, 2(5), 28-36. 